\title{
Soil organic phosphorus forms under different soil management systems and winter crops, in a long term experiment
}

\author{
Tales Tiecher $^{a \star}$, Danilo Rheinheimer dos Santos ${ }^{a}$, Ademir Calegari ${ }^{b}$ \\ a Department of Soil Science, Federal Univers ity of Santa Maria (UFSM), Roraima Avenue, Number 1000, \\ Santa Maria, Rio Grande do Sul State, Brazil

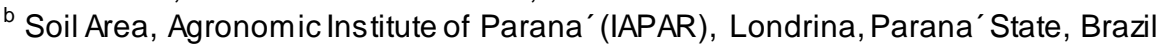

\begin{abstract}
A B STRACT
Organic phosphorus (P) is an important source of phosphate for plants both in natural environments and in cultivated soils. Growing plants with high P recycling capacity may increase the importance of organic forms in phosphate availability mainly in undisturbed soils. The aim of this study was to evaluate the effect of long period of cultivation of different winter species under different soil management systems in the distribution of soil organic $P$ forms, in the $P$ content stored into the soil microbial biomass (SMB) and in the acid phosphatase enzyme activity. The experiment was established in 1986 with six winter treatments (blue lupine, hairy vetch, oat, radish, wheat and fallow) implanted in a Rhodic Hapludox in southern Brazil, under no-tillage system (NT) and conventional tillage system (CT). The crops were cultivated with rational use of chemical phosphate fertilizer, according to plant needs and soil type maintaining high levels of soil organic carbon leading to P organic form accumulation. Growing crops during the winter period in highly weathered subtropical soil increases the importance of microbial interactions in the P cycle, especially in the NT, where a large amount of crop residues is annually added to the soil surface, increasing soil organic $\mathrm{P}$ level, $\mathrm{P}$ content stored into the SMB and acid phosphatase enzyme activity.
\end{abstract}

